\title{
Effect of Gable Roof Angle on Streamlines and Pressure Coefficient for an Isolated Building
}

${ }^{* 1}$ Lip Kean Moey, ${ }^{2}$ Man Fai Kong, ${ }^{3}$ Vin Cent Tai, ${ }^{4}$ Tze Fong Go

${ }^{123}$ Centre for Modelling and Simulation, Faculty of Engineering, Built Environment \& IT, SEGi University

${ }^{4}$ Centre for Advance Materials and Intelligent Manufacturing, Faculty of Engineering, Built Environment \& IT, SEGi University

* moeylipkean@segi.edu.my

\begin{abstract}
The airflow characteristics around and within an isolated gable roof building was investigated using CFD simulation based on steady RANS computation. Model validation and grid sensitivity analysis were conducted to ensure the reliability of the results. Three different roof pitches of gable roof namely $15^{\circ}, 25^{\circ}$ and $35^{\circ}$ were considered in this study. The model validation results show well agreement with those of Tominaga et al. (2015). In general, the streamline and pressure coefficient were found to be significantly depending on the roof pitch. The streamline shows the velocity at the inlet opening and outlet opening increased as the roof pitch increase except the roof opening outlet increased between $15^{\circ}$ and $25^{\circ}$ then decreased between $25^{\circ}$ and $35^{\circ}$. The spatial distribution of pressure coefficient at the windward side and the interior of the building decreased as the roof pitch increased. The difference in the flow fields of $25^{\circ}$ and $35^{\circ}$ roof pitch is large with the presence of window and roof opening relative to the difference between $15^{\circ}$ and $25^{\circ}$ roof pitch. In terms of spatial distribution of pressure coefficient and streamline, steeper roof pitch is more preferable.
\end{abstract}

Keywords: Gable Roof, Computational Fluids Dynamics (CFD), Roof Pitch, Steady RANS

\section{Introduction}


Malaysia as a tropical country enduring long-term solar heat attack, global warming and greenhouse effect. The Earth surface temperature has increased by $1^{\circ} \mathrm{C}$ over the past century (Aizebeokhai, 2009). The predicted temperature rise for the coming century is even unheard-of, which is ranged between $3.7^{\circ} \mathrm{C}$ to $4.8^{\circ} \mathrm{C}$ (Hassan et al., 2014). Furthermore, the overall energy consumption by sector also reported vigorous increment over the past decade. As reported by the Malaysian Energy Information Hub (MEIH), the energy consumption by residential has increased from 22.53-Terawatt hour (TWh) to the highest record of 31.16 TWh in just 7 years of time (Statistics - Malaysia Energy Information $H u b$ ). The greenhouse effect, global warming and the inclination of energy consumption contributed superbly in the climate changes and eventually demoted the indoor air quality and comfort.

Ventilation is a process aiding in improving the indoor air quality and comfort by introducing cool and fresh air from the clean source into a building and at the same time hot and polluted air from the indoor is expelled (Karava et al., 2007; Moey et al., 2018). In fact, ventilation also optimize the indoor thermal environment, prevent excessive moisture development and repel pollutants such as pollens, dust and contaminant in the air (Yang, 2004; Lim et al., 2013). Without the aid of ventilation, the indoor air quality demoted, excessive moisture building up especially in tropical country which may eventually lead to health problem like allergies and respiratory diseases, hygiene problems such as thriving of moulds and mites. Also, in terms of ventilation purpose, heat accumulation may occur in the roof and attics without the aid of ventilation. From that, HVAC (Heating, Ventilating and Air Conditioning) system is introduced to improve the indoor air quality, comfort and thermal environment. However, HVAC accounts up to $60 \%$ of domestic building energy consumption. Therefore, HVAC system as a mechanical ventilation method is not preferred.

Natural ventilation is a ventilation process utilizing the natural phenomena such as wind force and stack effect to introduce fresh air into interior and repel aged air to the exterior. Natural ventilation is believed to be the most effective, environmentally friendly, and is a passive way of cooling to supply clean and fresh air. Despite the fact that mechanical ventilation outperforms in any 
condition, natural ventilation with proper roof design is said to be possible for Malaysia even though the local air condition is classified as Class I annual average wind speed range from $1 \mathrm{~m} / \mathrm{s}$ to $5 \mathrm{~m} / \mathrm{s}$ (Lawan et al., 2013). Natural ventilation can be further categorized into two major groups which are the cross ventilation and stack ventilation. Cross ventilation is driven by wind flow creating a negative pressure in the indoor, and therefore the pressure difference directs the wind flow from outside to enter the building through apertures (Ramponi and Blocken, 2012a; Moey et al., 2018). Stack ventilation is driven by temperature difference between the inside and outside of the building (Ramponi and Blocken, 2012b; Lim et al., 2013; Aflaki et al., 2015). Due to the imperceptible temperature difference in the indoor and outdoor, cross ventilation is more suitable to be utilized in Malaysia.

Roof as the most exposing architecture features of a residential plays an important role in preventing humidity development and heat accumulation in building (Kindangen et al., 1997). In fact, the roof configuration have been perceived as an important parameter which greatly impact the flow pattern and characteristic around and within the building ( $\mathrm{Xu}$ and Reardon, 1998) and eventually control the pollutant dispersions (Huang et al., 2009; Yassin, 2011). There are a few well know roof configuration being utilized in Malaysia such as gable roof, hip roof, pyramidal roof, and venturi roof.

Computational Fluid Dynamics (CFD) is a combination of physics, flow technology, computer application, mathematics and mechanics knowledge, and it an authoritative tool to solve problem involving one or more phenomena such as fluids flow, heat change, mass transfer and chemical reaction (Raman et al., 2018; Zawawi et al., 2018). Tominaga et al. (2015) studied the airflow around a gabled-roof building with different tilt angles, specifically 3:10, 5:10, 7.5:10 to measure the turbulent kinetic energy, pressure coefficient and timeaveraged velocity around building. CFD simulation with RANS models, such as various $k-\varepsilon$ and the $k-\omega$ models were tested, validated with wind tunnel experiment. Furthermore, grid sensitivity analysis was conducted and effects of turbulence model were also evaluated to increase the accuracy of the simulation results. Tominaga et al. (2015) concluded the roof pitches affect the 
flow field including the streamline, turbulent kinetic energy distribution and pressure coefficient spatial distribution around the building.

Ozmen et al. (2016) studied the wind flow over various pitched gabled roofed low-rise building with open circuit L-2B wind tunnel experiment and numerically with RANS equation. The experiment and numerical analysis were carried out for gabled roof with different pitches included $15^{\circ}, 30^{\circ}$ and $45^{\circ}$. The working section has a dimension of $0.35 \mathrm{~m}$ height and width and $2 \mathrm{~m}$ length for wind tunnel experiment and tested model for both wind tunnel and numerical simulation sized L x W x H, 100mm x 50mm x 40mm. Anemometer and pressure transducers were used in the experiment to measure the mean velocity, turbulence and mean surface pressure. The results indicated that the mean velocity, turbulence kinetic energy and surface pressure are depending on the roof pitches. The relationship between the recirculation regions and critical suction on the roof was also determined. Besides, Realizable k- $\varepsilon$ and Standard k- $\varepsilon$ shows different degree of agreement at the prediction of mean velocity, turbulence kinetic energy and mean pressure coefficients (Ozmen et al., 2016).

The roof configurations is one of the most influencing factors affecting the ventilation rate, indoor air quality, comfort and thermal environment. In fact, the volume flow rate, pressure difference over building, and indoor air velocities rely strongly on the roof configurations (Peren et al., 2015). However, the studies on the effect of gable roof angle are very limited. In view of this, this study therefore is dedicated to investigate the effect of gable roof angle on streamlines and pressure coefficient in isolated building.

\section{CFD simulations: computational setting and parameters}

\subsection{Model cases}

In this study, an isolated building is chosen as the tested model. The model has a 1:50 scaled down dimension of $\mathrm{W} \times \mathrm{D} \times \mathrm{H}=100 \mathrm{~mm} \times 100 \mathrm{~mm} \times 80 \mathrm{~mm}$ which is corresponding to $5 \mathrm{~m} \times 5 \mathrm{~m} \times 4 \mathrm{~m}$ in real scale. The height of window opening and roof opening is $18 \mathrm{~mm}$ and $9 \mathrm{~mm}$ respectively. The center line of the window opening is at $y=0.04 \mathrm{~m}$ and the roof opening is at $0.0655 \mathrm{~m}$ from ground. The window openings and roof openings were placed at the windward 
and leeward wall of the model to improve the efficiency of the model.The wall thickness of the tested model is $2 \mathrm{~mm}$ as proposed by Ramponi et al. (Ramponi and Blocken, 2012b). In this study, three cases with different roof pitches namely $15^{\circ}, 25^{\circ}$ and $35^{\circ}$ are considered. Also, a reference model without any window opening was created with references to Tominaga et al. (2015) for model validation and comparison purposes.

\subsection{Computational domain and grids}

The simulations were done in a scaled down model. The tested model was modified based on the model tested in model validation. The computational domain was created with reference to the existing best practice guideline proposed by Franke et al. (2007) and Tominaga et al. (2008). The distance between inlet plane and windward wall of the tested model was constructed shorter, specifically $3 \mathrm{H}$ for the upstream instead of $5 \mathrm{H}$ as recommended by Franke et al. (2007) and Tominaga et al. (2015). This is to limit the extent of unintended streamwise gradient (Ramponi and Blocken, 2012a). The top and lateral wall of the flow domain were $5 \mathrm{H}$ away from the model and the downstream length was created for $15 \mathrm{H}$. Figure 1 shows the dimension of the gable roof building model modified based on the tested model in model validation. Figure 2 shows the dimension of computational domain where $\mathrm{H}$ is the effective height measured from ground.

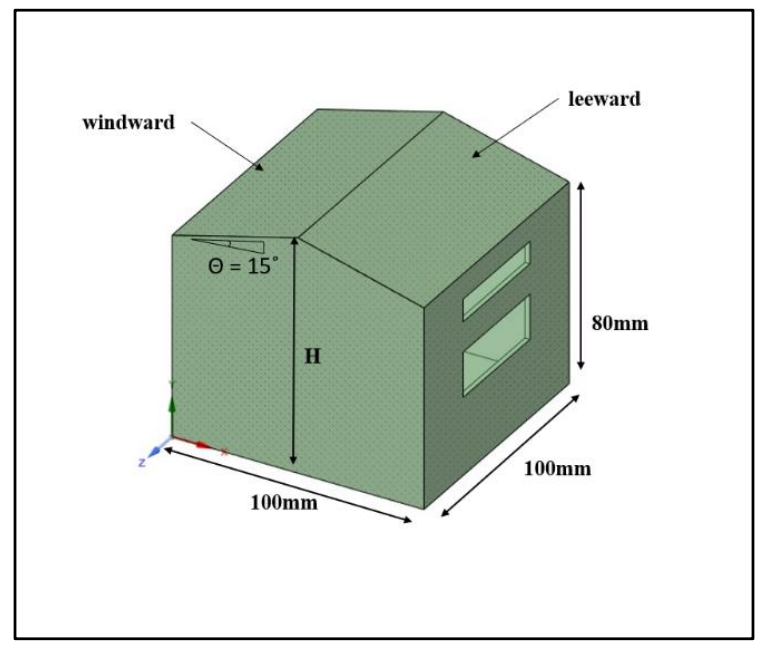

Figure 1. Dimension of $15^{\circ}$ gable roof building 


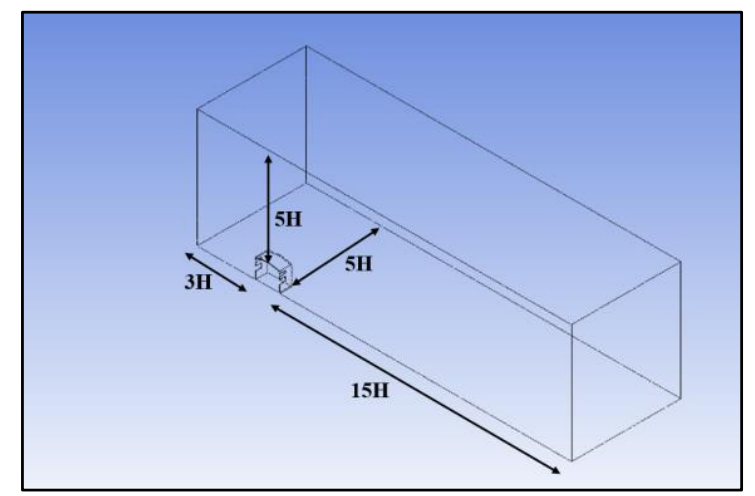

Figure 2. Dimension of computational domain

Mosaic $^{\mathrm{TM}}$ meshing technology was applied to the geometry due to its benefit of producing high quality octree hexahedron in bulk region. The Mosaic $^{\mathrm{TM}}$ meshing technology allows connection of elements automatically and conformally disregard the types of elements. The Mosaic ${ }^{\mathrm{TM}}$ also produces meshes with high quality and efficiency to solve the fluid flow around geometry with high complexity (Krishna et al., 2019). The geometry was first meshed with tetrahedral element using scope sizing function in Ansys Fluent and then converted into Poly-Hexcore. Figure 3 shows the meshing detail of the tested model.
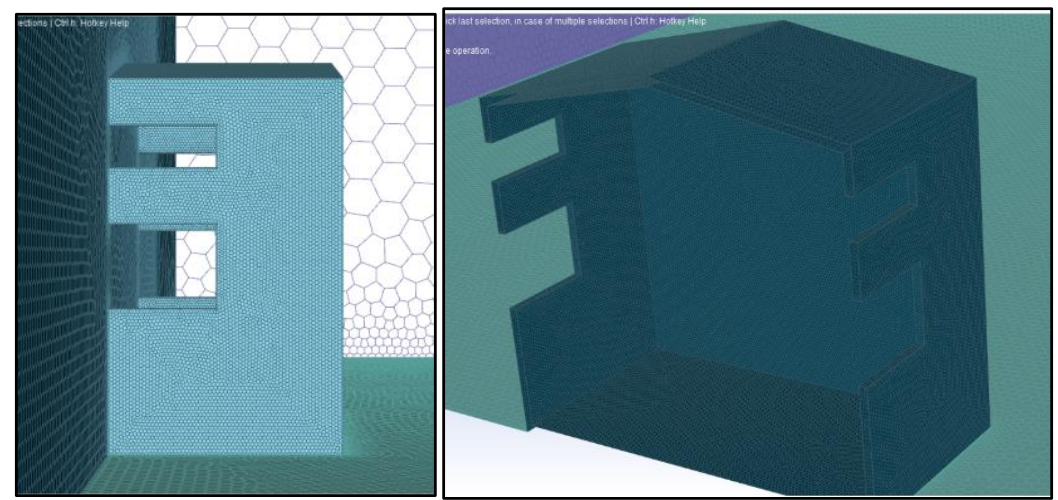

Figure 3. Meshing detail of tested model

\subsection{Boundary condition}

The boundary condition imposed at the inlet plane were based on the measured vertical profile of mean wind speed and turbulence intensity. The 
inlet wind speed profile was determined using equation (1), where $\mathrm{z}_{0}=$ $0.00003 \mathrm{~m}, \kappa$ is the von Karman constant $(0.42), \mathrm{z}$ is the height coordinate and the $\mathrm{u}_{\mathrm{ABL}}$ is the atmospheric boundary layer friction velocity. The turbulent kinetic energy, $\mathrm{k}$ was calculated using equation (2), from the mean wind velocity and measured turbulence intensity $\mathrm{I}_{\mathrm{u}}$. Tominaga et al. suggested $\alpha=1$ which was also selected for this study (Tominaga et al., 2008). The turbulence dissipation rate, $\varepsilon$ was determined by the equation (3).

$U(z)=\frac{u_{A B L}^{*}}{\kappa} \ln \left(\frac{z+z_{0}}{z}\right)$

$k(z)=\alpha\left(I_{u}(z) U(z)\right)^{2}$

$\varepsilon(z)=\left(\frac{u_{A B L}^{* 3}}{\kappa\left(\mathrm{z}+z_{0}\right)}\right)$

For the ground surface, standard wall function with roughness height modification were applied (Launder and Spalding, 1974; Cebeci and Bradshaw, 1977). This is because the building is expected to be built on a grass-covered terrain with scaled down roughness length of $0.00003 \mathrm{~m}$. The sand grain roughness $\mathrm{k}_{\mathrm{s}}$ was determined using equation (4) which was derived by Blocken et al. (2007) describing the consistency relationship between $\mathrm{k}_{\mathrm{s}}$ and roughness constant $C_{s}$ (Blocken et al., 2007), where the chosen value for $C_{s}$ is 0.42 .

$k_{s}=\frac{9.793 z_{0}}{C_{S}}$

At the outlet plane, zero static pressure was applied. Symmetry type was applied to the symmetry plane. Boundary condition at the top and lateral wall of the computational domain were imposed with zero normal gradients and velocities which is corresponding to zero-shear condition. Standard wall function with zero roughness height was applied to the tested model which correspond to no-slip wall.

\subsection{Solver setting}


In this study, the simulations were conducted using commercial Ansys product version 19.2. The 3D steady RANS equation was solved together with standard k- $\varepsilon$ turbulence model. Standard k- $\varepsilon$ model was selected due to better accuracy provided for ABL (Argyropoulos and Markatos, 2015). SIMPLE algorithm was selected for this study based on Green Gauss node based spatial discretization in combination with second order pressure interpolation and second order discretization schemes both applied to the convection terms and viscous terms of the governing equation. Convergence were expected to be obtained when all the scaled residuals are receding and reached a minimum of $10^{-7}$ for $\mathrm{x}-, \mathrm{y}$ - and z-velocity and $10^{-6}$ for continuity, $\mathrm{k}$ and $\varepsilon$.

\subsection{Grid sensitivity analysis}

A grid sensitivity analysis was conducted for the reference model to ensure the the results are grid independent. Four different grids with various sizing and cell counts (192846, 2043207, 2191158 and 2740986) were created for the analysis. The results from these four meshes were compared in terms of streamwise wind velocity ratio $\left(\mathrm{U} / \mathrm{U}_{\text {ref }}\right)$ at the inlet and outlet opening and along the center line of the opening. Note that $U$ is the 3D streamwise velocity vector and $U_{\text {ref }}=6.97 \mathrm{~m} / \mathrm{s}$ is the reference wind speed measured at the bulding height $(\mathrm{H}=80 \mathrm{~mm})$. The results of this analysis will be discuss later in section 3.1.

\subsection{Model validation}

The wind-tunnel experiment and CFD simulation conducted by Tominaga et al. (2015) were used for model validation. Tominaga et al. (2015) conducted a boundary layer wind tunnel experiment investigating the airflow around isolated gable roof building with different angle namely the $16.7^{\circ}, 26.6^{\circ}$ and $36.9^{\circ}$. CFD simulation performed by Tominaga et al. using with steady RANS computation. Four different turbulence model namely the standard k- $\varepsilon$, the RNG k- $\varepsilon$, the realizable $\mathrm{k}-\varepsilon$ and the k- $\omega$ SST models were tested. In this study, ANSYS FLUENT 19.2 was used to perform the 3D RANS computation in combination with standard k- $\varepsilon$ turbulence model. The tested model was created without window opening and roof opening for validation. The simulation results were compared to the wind-tunnel measurement and the results of CFD 
simulation by Tominaga et al. (2015) in terms of streamwise velocity ratio around the building. The comparisons and the validation results will be discussed in section 3 .

\section{Results and discussion}

\subsection{Grid sensitivity analysis}

Figure 4 shows the comparison between the percentage error of the measured velocity for four different grids. The average percentage errors for four different grids, specifically between 1928460 cell counts, 2043207 cell counts, 2191158 cell counts and 2740986 cell counts were $31.69 \%, 12.36 \%$ and $1.61 \%$ respectively. It is clearly seen that the percentage error reduces as the cell counts increased. Minor difference is observed between 2191158 cell counts and 2740986 cell counts. This indicates that the results obtained from 2191158 cell counts and 2740986 cell counts are mesh independent. Therefore, the grid sizing of 2191158 cell counts was retained for further study.

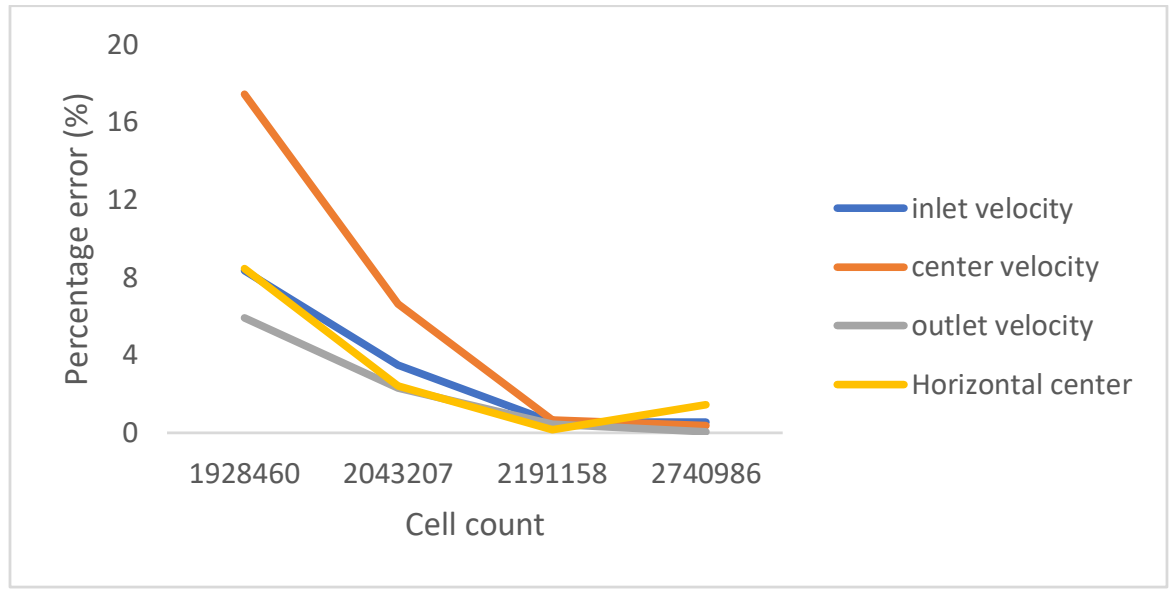

Figure 4. Percentage error between four different meshing.

\subsection{Model validation}

A model validation was performed with reference to Tominaga et al. (2015) in terms of spatial distribution of pressure coefficient and also streamlines. Figure 5 compares the streamline of reference model with the results obtained by Tominaga et al. (2015). Large recirculation region is observed at the leeward side of the building and small recirculation region is spotted at the 
lower corner of the windward side of the building. Figure 6 compares the spatial distribution of pressure coefficient of reference model with the results obtained by Tominaga et al. (2015).Positive pressure in front of the building model is observed due to the blockage caused by the building in both results from present study and from Tominaga et al. (2015). Negative peaks occurs at the windward corner was also observed in both results. The building model was therefore retained for the following investigation since similar results to Tominaga et al. was obtained (Tominaga et al., 2015).
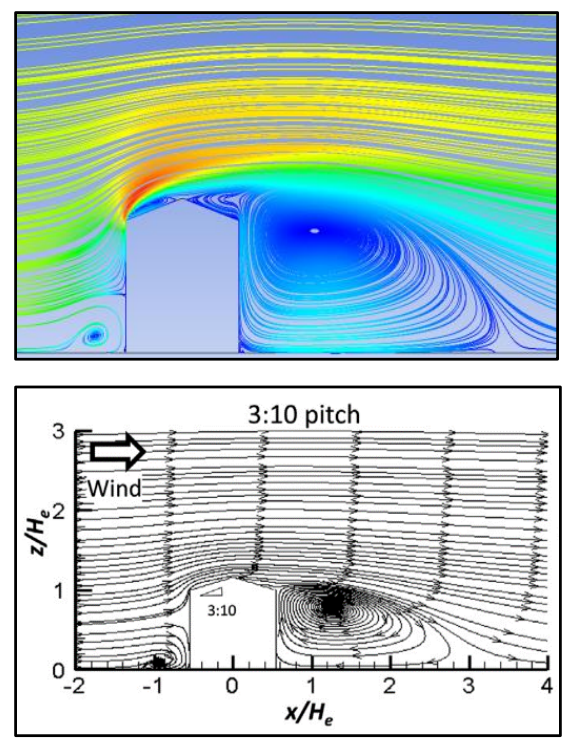

(a)

(b)

Figure 5. Comparison of streamline velocity between (a) reference model and (b) CFD results by Tominaga et al. (2015)

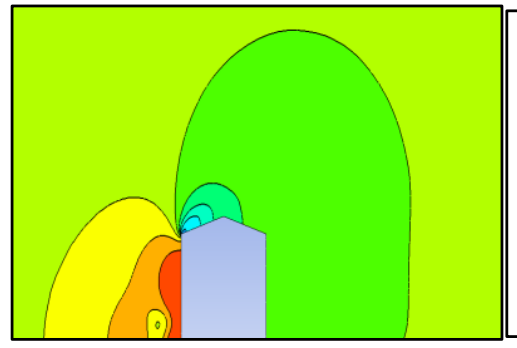

(a)

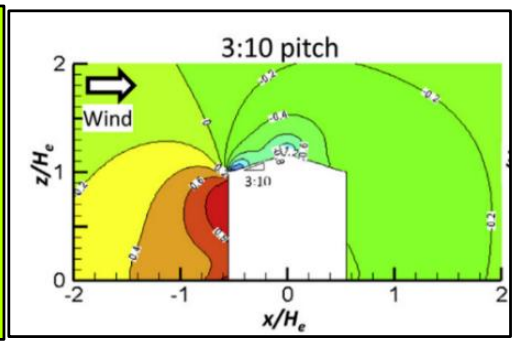

(b)

Figure 6. Comparison of pressure coefficient contour of (a) reference model and (b) CFD results by Tominaga et al. (2015) 


\subsection{Streamlines}

Figure 7 compares the streamlines velocity of $15^{\circ}, 25^{\circ}$ and $35^{\circ}$ roof pitch. According to Tominaga et al, the recirculation region at the leeward side of the building becomes larger as the roof pitch become steeper (Tominaga et al., 2015). However, window opening and roof opening has been added to the model, therefore the wind flow able to flow through the opening. The center of the recirculation eddy behind the building tends to move upwards but the wind flow through the outlet opening disturbed the recirculation region behind the building. It is clearly shown that the flow field noticeaably change between $15^{\circ}$ and $25^{\circ}$. Behind the building, although no reverse flow is observed in $15^{\circ}$ roof pitch cases, reverse flow is observed and groiwing larger in $25^{\circ}$ and $35^{\circ}$ roof angle cases. The velocity through the opening is observed to be higher as the roof pitch increase. The overall streamline results show an agreement to the results obtained by Tominaga et al. (Tominaga et al., 2015).

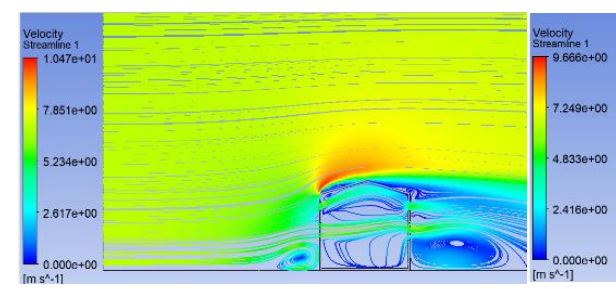

a)

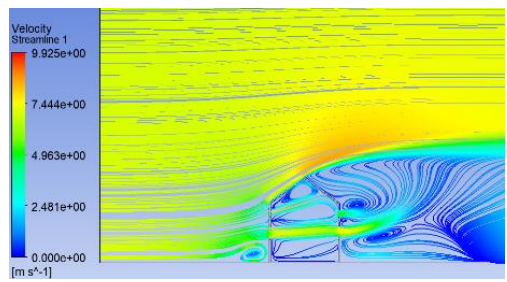

(c)

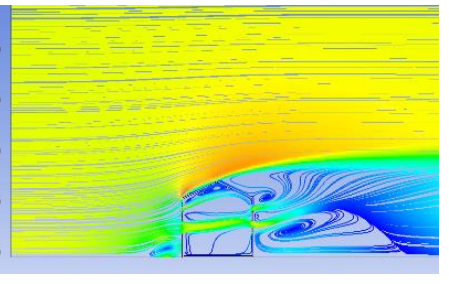

b)

3.4 Spatial distributions of pressure coefficient. 
Figure 8 compares the spatial distribution of static pressure as expressed by pressure coefficient. Positive pressue was observed at the windwaard wall of the building, However, the positive pressure become smaller as the roof pitch increased. This is due to the presence of window opening and roof opening on the windward wall of the building. Negative peak was observes at the windward corner near roof and rigde for the $15^{\circ}$ roof pitch. The negative peak reduces as the roof pitch increased to $25^{\circ}$ and even diminish in the case of $35^{\circ}$ roof pitch. The indoor pressure coefficient also observed to be reducing as the roof pitch increased. The increment of negative pressure of model interior caused the incoming wind to enter the building in increasing velocity.

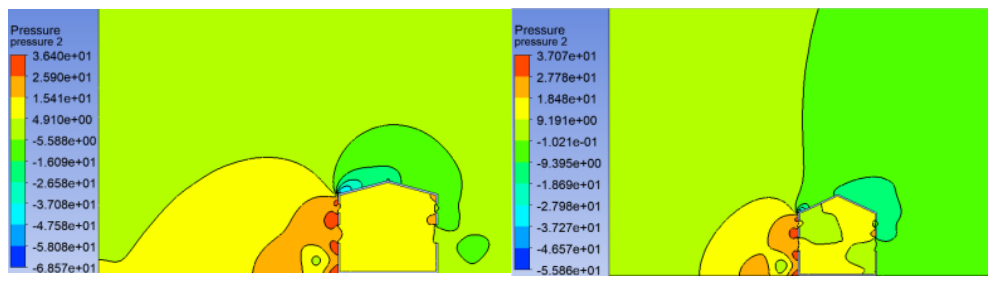

a)

b)

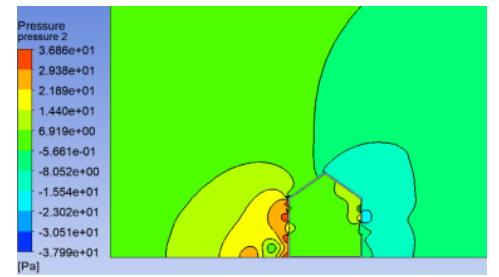

(c)

Figure 8. Spatial distribution of pressure coefficient of (a) $15^{\circ}$ roof pitch, (b) $25^{\circ}$ roof pitch and (c) $35^{\circ}$ roof pitch

\section{Conclusion}

In present study, the airflow characteristics around and within an isolated gable roof building with different roof angles namely the $15^{\circ}, 25^{\circ}$ and $35^{\circ}$ are investigated and analysed by the means of CFD simulation based on 3D steady-RANS with model validation with the results obtained from Tominaga et al. (2015). The model validation results show well agreement with the results obtained by Tominaga et al. (2015). The CFD simulation results show that the 
streamline and spatial distribution of pressure coefficient depends on the roof pitch. The recirculation region at the leeward side of the building tends to move upwards and become larger as the roof angle increased. However, with the presence of window and roof opening, the recirculation region is disturbed by the wind flow through the apertures. Positive pressure was observed at the windward side of the building due to the wind blockage by the building wall. The positive pressure was reduced by the presence of the openings by allow the wind to flow through the openings. The negative peaks occur at the windward corner reduces and eventually diminish as the roof pitch increased. In terms of spatial distribution of pressure coefficient and streamline, steeper roof pitch is more preferable for better ventilation.

\section{Acknowledgement}

The authors were thankful to SEGi University, Kota Damansara and anonymous reviewers for the support, remarks and propositions given to accomplish the presentation of this paper.

\section{References}

Aflaki, A., Mahyuddin, N. and Mahmoud, Z. (2015). A review on natural ventilation applications through building fac, ade.pdf.

Aizebeokhai, A.P. (2009). Global warming and climate change: Realities, uncertainties and measures. International Journal of Physical Sciences. 4(13), pp. 868-879.

Argyropoulos, C.D. and Markatos, N.C. (2015). Recent advances on the numerical modelling of turbulent flows. Applied Mathematical Modelling.

Blocken, B., Stathopoulos, T. and Carmeliet, J. (2007). CFD simulation of the atmospheric boundary layer: wall function problems. Atmospheric Environment.

Cebeci, T. and Bradshaw, P. (1977). Momentum transfer in boundary layers.

Hassan, N.A., Hashim, Z. and Hashim, J.H. (2014). Impact of Climate Change on Air Quality and Public Health in Urban Areas. Asia-Pacific Journal of Public Health. 28, pp. 38S-48S.

Huang, Y., Hu, X. and Zeng, N. (2009). Impact of wedge-shaped roofs on airflow and pollutant dispersion inside urban street canyons. Building and Environment. Elsevier Ltd, 44(12), pp. 2335-2347.

Karava, P., Stathopoulos, T. and Athienitis, A. K. (2007). Wind-induced natural ventilation analysis. Solar Energy. 81(1), pp. 20-30. 
Kindangen, J., Krauss, G. and Depecker, P. (1997). Effects of Roof Shapes on Wind-Induced Air Motion Inside Buildings. Building and Environment. 32(1), pp. 1-11.

Krishna, Z., Gandhar, P., Alan, V. and Balasubramanyam. (2019). Ansys Mosaic Poly-Hexcore Mesh for High-Lift Aircraft Configuration. 21 st Annual CFD Symposium, (September), pp. 1-11.

Launder, B.E. and Spalding, D. B. (1974). The numerical computation of turbulent flows', Computer Methods in Applied Mechanics and Engineering.

Lawan, S., Abidin, W., Chai, W., Baharun, A. and Masrun, T. (2013), Reviewing Wind Speed and Energy Distribution in Malaysia. European Academic Research.

Lim, C.H., Omidreza S., Sopian, K., Yusof Sulaiman, M., Mat, S., Salleh, E. and $\mathrm{Ng}$, K.C. (2013). Design configurations analysis of wind-induced natural ventilation tower in hot humid climate using computational fluid dynamics. International Journal of Low-Carbon Technologies. 10(4), pp. 332-346.

Moey, L.K., Adam, N., Ahmad, K. and Abdullah, L.C . (2018), Wind Tunnel Study of Different Roof Geometry Configurations for Wind Induced Natural Ventilation into Stairwell in Tropical Climate, Wind Tunnel Study of Different Roof Geometry Configurations for Wind Induced Natural Ventilation into Stairwell in Tropical Climate. 13(5), pp. 2635-2647.

Ozmen, Y., Baydar, E. and van Beeck, J.P.A.J. (2016). Wind flow over the low-rise building models with gabled roofs having different pitch angles. Building and Environment. Elsevier Ltd, 95, pp. 63-74.

Peren, J. I., Van Hood, T., LEite, B.C.C and Blocken, B. (2015). Impact of roof geometry of an isolated leeward sawtooth roof building on crossventilation: Straight, concave, hybrid or convex? Journal of Wind Engineering and Industrial Aerodynamics. Elsevier, 145(May), pp. 102114.

Raman, R.K., Dewang, Y. and Raghuwanshi, J. (2018). A review on applications of computational fluid dynamics. (July).

Ramponi, R. and Blocken, B. (2012a). CFD simulation of cross-ventilation flow for different isolated building configurations: Validation with wind tunnel measurements and analysis of physical and numerical diffusion effects. Journal of Wind Engineering and Industrial Aerodynamics. Elsevier, 104-106, pp. 408-418.

Ramponi, R. and Blocken, B. (2012b). CFD simulation of cross-ventilation for a generic isolated building: Impact of computational parameters. Building and Environment.

Statistics - Malaysia Energy Information Hub (no date). Available at: https://meih.st.gov.my/statistics

Tominaga, Y., Yoshihide, M., Akashi, Y., Ryuichiro, K., Hiroto, N., Tsuyoshi Y., Masaru S. and Taiichi. (2008). AIJ guidelines for practical applications 
of CFD to pedestrian wind environment around buildings. Journal of Wind Engineering and Industrial Aerodynamics.

Tominaga, Y.. Akabayashi Y., Kitahara, T. and Arinami Y. (2015). Air flow around isolated gable-roof buildings with different roof pitches: Wind tunnel experiments and CFD simulations. Building and Environment. Elsevier Ltd, 84, pp. 204-213.

Xu, Y. L. and Reardon, G. F. (1998). Variations of wind pressure on hip roofs with roof pitch. Journal of Wind Engineering and Industrial Aerodynamics, 73(3), pp. 267-284.

Yang, T. (2004). SCHOOL OF CIVIL ENGINEERING CFD and Field Testing of a Naturally Ventilated Full-scale Building'.

Yassin, M. F. (2011). Impact of height and shape of building roof on air quality in urban street canyons. Atmospheric Environment. Elsevier Ltd, 45(29), pp. 5220-5229.

Zawawi, M. H., Saleha, A., Salwa, A., Hassan, N. H., Zahari, N. M., Ramli, M. Z. and Muda, Z.C. (2018). A review: Fundamentals of computational fluid dynamics (CFD). AIP Conference Proceedings, 2030. 